Kaleidoscope

\title{
Szimulákrum és Mátrix
}

\section{Simulacra and Mátrix}

\section{Gerdesits Pál}

ELTE Filmtudományi mesterképzés

gerdesits.pal@gmail.com

Initially submitted March 20, 2020; accepted for publication Apr.30, 2020

\begin{abstract}
Jean Baudrillard's Simulacra and Simulation in 1981 admittedly served as a main inspiration for the idea behind the Wachowski sisters' Matrix trilogy. In the first (and major) part of my study, I am focusing on the main points of Baudrillard and the way the film interprets them. There are some ideas that the Wachowskis took literally (even borrowed the phrases as well, like the Desert of the Real) but in some other cases they recontexted things (like the simulacra of the matrix is a collective construction of connected minds living in tanks) for artistic purposes. In the second part of my essay, I focus on the interference caused by the elemental differences between Baudrillard's original thoughts and the movies based on of them. My main goal here was to highlight these misunderstandings and stylistic techniques as they seemed to be problemetic in the context of the original text.
\end{abstract}

Kulcsszavak: Jean Baudrillard, Wachowski, Matrix, film, Hollywood, William Merrin, szimulákrum, kép, posztmodern

Keywords: Jean Baudrillard, Wachowski, Matrix, film, Hollywood, William Merrin, simulacra, simulacrum, picture, postmodernism

\section{Bevezető}

Tagadhatatlan a kapcsolat Jean Baudrillard 1981-es A szimulákrum elsöbbsége címü írása és a Wachowski testvérpár 1999-ben debütált Mátrix ${ }^{1}$ címü filmje között. Mind az írásmü, mind annak tartalma megjelenik a filmben, egyrészt föszereplönk, Neo e könyvbe rejti az általa (illegálisan) letöltött szoftvereket tartalmazó adathordozókat és az ezért kapott pénzt, másrészt a film egy pontján Morpheus száját hagyja el a Baudrillardtól kölcsönzött valóság sivataga ${ }^{2}$ kifejezés. A film föszereplöinek kötelező olvasmány volt Baudrillard szövege. ${ }^{3}$

Azt szeretném bemutatni, hogy miképp jelennek meg a Baudrillard által felvetett gondolatok, problémák a filmben, illetve, hogy miért utasította el (teljes joggal) Baudrillard, hogy a Mátrixra mint gondolatainak filmes interpretációjára hivatkozzanak. Elemzésem elsősorban az első filmre korlátozódik, de azokat a történet és értelmezés szempontjából fontos pontokat is figyelembe veszem, amelyek a trilógia másik két epizódjához köthetőek.

\footnotetext{
${ }^{1}$ Bővebben lásd: a Mátrix IMDb oldala https://www.imdb.com/title/tt0133093/ (utolsó letöltés dátuma: 2020. 01. 31.)

${ }^{2}$ Mind Morpheus, mind Baudrillard e sivataggal kezdi meg a világ bemutatását, előbbi a frissen felébresztett Neohoz, utóbbi az olvasóhoz szól e szavakkal.

${ }^{3}$ Erről tanúskodik például ez a Keanu Reeves-szel készített interjú is: https://www.youtube.com/watch?v=5zdUpQkDIr0 (utolsó letöltés dátuma: 2020. 03. 30.)
} 


\section{Kép és szimulákrum}

Baudrillard a szimulákrum ${ }^{4}$ és kép közti különbséget úgy határozza meg, hogy amíg a kép mindig valaminek a képe, tehát olyan reflexió, amelynek létezése függ egy, a valóságban is fellelhető referenciaalaptól, ${ }^{5}$ addig a szimulákrum ettől független, valóságossága, és ezzel egyenértékü hamissága is, önmagában rejlik.

Mind a film, mind pedig Baudrillard a térkép-terület szembeállítással igyekszik érzékeltetni e különbséget: a szimulákrum (illetve a Mátrix) elsőbbsége ugyanis abban rejlik, hogy „, a térkép elöbbre való a területnél”, 6 tehát nem csak hogy létezik, de hiperrealitásából fakadóan valóságosabbnak is hat, mint az, ,igazi”. Ez egyet jelent a metafizika halálával is, ugyanis ,nincs többé tükör a lét és a megjelenés formái közt, a valódi és fogalma között", 7 viszont van valami, ami a valódinál valódibbnak hat.

A film talán ennél is messzebbre merészkedik, amikor nem pusztán a Mátrix, hanem a Mátrixban élő Én valóságosságát is megkérdőjelezi. A történet egy pontján Neo aggódva veti fel a kérdést, hogy mi van akkor, ha minden emléke hazugság (ezzel az Én és az élettörténet közti azonosságot, illetve az élettörténet nélküli Én kérdéskörét villantva fel), mire Trinity azt válaszolja, hogy ez mindössze annyit jelent, hogy a Mátrix nem határozhatja meg, hogy ki is ö valójában.

\section{Lascaux és Disneyland}

Baudrillard a szimulákrumot mint tökéletes hazugságot Disneylandhez hasonlítja, ahogy a tömeg-effektus, a haláltól megtisztított, kimerevített idő és az egész hiperrealitásából fakadó pezsgés vagy vibrálás egyfajta vallásos extázisba ejti a látogatókat, és nyilvánvaló müvisége elfelejtteti velük, hogy a minden más, tehát a külvilág az, ami valójában (és szintén) hamis. Mindezt ráadásul kontrasztba állítja a parkoló példájával, ahol a látogatókat rideg rendezettségben terelik vissza az autójuk magányába.

A filmben bemutatott Mátrix is ezen az analógián alapul. A pezsgő (bár többnyire eléggé noirosan világított) kollektív szimuláció a maga érzékiségében ,több”, mint a valóság megtépázott, szürke romjai. Elég csak az áruló Cypherre gondolnunk, aki társai és a Zion feladásáért cserébe, miközben szinte nyögve eszi a sztéket - amiről pontosan tudja, hogy valójában csak, mint hamis élmény létezik - azt kéri, hogy hadd legyen gazdag és fontos. Inkább válik a Mátrix szimulákrum-élményének áldozatává, minthogy szembe nézzem a rideg valósággal, a lényeg, hogy ne emlékezzen semmire.

A Baudrillard szövegben szó esik a Lascaux-i barlangról és annak mesterségesen felépített, tökéletes másáról is. Ahogy az eredeti barlang, úgy a valóság is az ember telhetetlensége révén vált használhatatlanná, ${ }^{8}$ és pontosan ez tette indokolttá egy vonzóbb, javítható másolat létrehozását. Bár gondolhatnánk azt, hogy a Mátrix valójában csak egy letünt kor képe, ${ }^{9}$ egy Lascaux-féle rekonstrukció, véleményem szerint a kétely már önmagában szimulákrummá emeli, ugyanis sohasem tudhatjuk meg, hogy milyen volt az eredeti. Ráadásul az a Mátrix, amelyben hőseink tevékenykednek, a Mátrix egy sokadik verziója, biztos, hogy nem a „régi valóság” szerint hozták létre.

\footnotetext{
${ }^{4}$ A szöveg során hü maradok Baudrillad írásmódához, azaz a szimulákrumot mint a szimuláció metaforáját használom.

${ }^{5}$ Legfeljebb a bemutatás valóságosságában lehet eltérés kép és kép, illetve kép és valóság közt.

${ }^{6}$ Baudrillard, Jean: A szimulákrum elsőbbsége. In: Kiss, Kovács, Odorics (eds.): Testes könyv I. Szeged: Ictus és Jate, 1996. p. 161.

7 ibid. p. 162.

${ }^{8}$ Lascaux-t a turizmus, a valóságot pedig a kényelem falta fel.

${ }^{9}$ Amennyiben figyelmen kívül hagyjuk például az előbbi hamis-sztéket és magára a világ leképezésére gondolunk, olyasmire, mint amire az utolsó film is kifut, hogy szabad lesz a döntés mindenki számára afelett, hogy el szeretné-e hagyni a Mátrixot.
} 
Kaleidoscope

\section{Termelés és újrahasznosítás}

A film egyrészt esztétizálja Baudrillard gondolatait, másrészt ezt az esztétikumot dramaturgiájának központi szervezőelemévé is teszi. Az ember, mint nagyipari mennyiségben termeszthető energiaforrás ugyanis több gondolat szintézise.

Elöször is, Baudrillard magán az önmagából kifordult fogyasztói társadalmon botránkozik meg, amely örületében a saját maga teremtette szimulákrum csapdájába esett. A film azzal mutatja be a fogyasztás nélküli fogyasztás (vagy birtoklás nélküli birtoklás) abszurditását, hogy szó szerint kiemeli azt a valóságból, és hatalmas felkiáltójelek közepette csapja az arcunkba a tényt, miszerint minden, amit konzumálni hiszünk, valójában csak egy szimulákrum keltette neurobiológiai kisülés az idegrendszerünkben. Ez pedig, ha kivesszük a képből a csöveket, robothadsereget és szuperszámítógépeket, semmivel sem hamisabb, mint amit Baudrillard ír, mindössze - paradox módon - egy fogyasztási cikkbe ${ }^{10}$ van csomagolva. Mindkét mü ugyanazt mondja, miszerint mi magunk tartjuk életben - tehát tápláljuk - ezt a rendszert azzal, hogy elfogadjuk valóságként, valóságunkként.

Ezt az összefonódást Baudrillard a következőképp fogalmazza meg: „, Ön a hír, ön a társadalom, ön az esemény, ön van érintve, öné a szó stb. "E visszafordulás áltat lehetetlenné válik a modellt, a hatalmat, a tekintetet, a médiumot állandósitani, mivel Ön már mindig is ott van a másik oldalon.". " Az emberi élet tökéletesen passzív aktivitássá redukálódott, egy olyan tér-és idö-független semlegességgé, amely valóban nem sokban tér el attól, amit a filmben is láthatunk. „Az irány leblokkolása. Itt kezdödik a szimuláció” ${ }^{12}$

Másodszor, az újrahasznosítás: Baudrillard élesen rávilágít kora szociális paradoxonaira, amikor például az újrahasznosítással kapcsolatban írja, hogy „Az emberek nem tekintenek többé egymásra, de vannak erre intézmények. Többé nem érintik meg egymást, de van érintésterápia. Nem járnak már gyalog, de kocognak $s t b . "$ "' Az újrahasznosítás, Baudrillardot követve, a problémák, a rendszer elidegenedett mivolta által szült problémák átdolgozása különböző ál-közösségi fogyasztási cikkek formájába. Ezt megint csak szó szerint veszi a film, hisz a Mátrix ál-valóságában vágyunk és teszünk, miközben a fent már leírt mozdulatlanságban éljük le az életünket. Ráadásul az újrahasznosítás, mint metafora tovább gyürüzik, miképp az elhunytak cseppfolyósított maradványaival táplálja a gép a még élőket.

Harmadrészt: Baudrillard az etnológiáról írva ${ }^{14}$ kifejti, hogy miként az etnológia megszünteti önmagát azáltal, hogy az lezárja az őserdőt a taszadájok körül, ezáltal elzárva magát saját tárgyától, úgy válik a szabad ember is veszélyeztetett fajjá Zion rezervátumába gyüjtve, valahol a Föld mélyén. Ugyanúgy, ahogy az indián „az etnológia elötti összes virtuális indián szimulált modelljévé válik" ${ }^{15}$, úgy lesz az a marék ember ${ }^{16}$ is az ember virtuális modellje egy nem-virtuális térben. Miként az indiánoknál a kulturális, úgy a gépek esetében a technológiai felsőbbrendűség egyik szimptómájaként jelenik meg a másik, alárendelt faj tenyésztése, termelése.

\footnotetext{
${ }^{10}$ Egy a Warner Brothers által forgalmazott, ausztál-amerikai koprodukcióban, 63 millió dolláros költségvetésből készült hollywoodi szuperprodukció formájában. Persze nevezhetjük ezt kulturális terméknek is, a lényegen nem változtat.

11 ibid. p. 183.

12 ibid. p. 184.

13 ibid. p. 170.

${ }^{14}$ Pontosabban az anti-etnológiáról.

15 ibid. p. 166.

${ }^{16}$ Mint későbbiekben megtudhatjuk, a Mátrix újraindításánál ráadásul meghatározott számú férfit és nőt „engednek szabadon”. http://www.kaleidoscopehistory.hu

Gerdesits Pál
} 
Kaleido scope
Journal of History of Culture, Science and - Medicine

DOI: $10.17107 /$ KH.2020.20.169-174

\section{A Kiválasztott(ak) és Smithek}

Baudrillard az olyan eröszakos cselekedeteket, amelyekröl a médiában értesülhetünk (például egy gépeltérités) szimulációnak tartja, mert a „média rituális müködése és kódja elöre betervezi azokat, megrendezésében és lehetséges következményeiben anticipálja”" ${ }^{17}$, tehát a „kapuörnek” indifferens az esemény tartalma abban az értelemben, hogy csak formailag hat rá, hiszen minden helyzetre egy elözetes sablon alapján reagál.

Ebben az értelmezésben viszont mind az ügynökök, mind pedig Neoék egy elöre meghatározott protokoll szerinti szimulációt hajtanak végre a Mátrixon kívül és belül egyaránt. Az ügynökök, lekódolt vírusírtó program révén, bevett koreográfia alapján bánnak el a behatolókkal, ahogy Morpheus és csapata is gyakorlatok során betanult helyzeteket járnak le „élesben”. Elég csak a tanulóprogramokra gondolnunk, amelyeket ők maguk írtak, ezáltal nem csak a szabályrendszerüket, de az események pontos helyét és idejét is ismerik ${ }^{18}$. Ilyen szimuláció továbbá az is, ahogy az embereket „felébresztik” és újra alkalmassá teszik a Mátrixba való visszatérésre, de talán ami még fontosabb, hogy maga $A$ Kiválasztott keresése is puszta szimulákrum. Neo nem egyedül látogatja meg az Orákulumot, számtalan ,jelölt" esélyes még erre a pozícióra, akikre feltehetően ugyanúgy, hasonló szempontok és elváások alapján figyelt fel valaki, és követve a tánclépéseket végül elhozta az Orákulumhoz. Ahogy „az egymást követő färaók mindig egy és ugyanazon személyt testesitettek meg"19, $\mathrm{Neo}$ is a sokadik Kiválasztott. Hasonlóan egyébként Smith-szel, csak míg a Kiválasztott időben ${ }^{20}$, addig Smith térben van jelen többszörösen, de mégis egyként ${ }^{21}$. Arról nem is beszélve, hogy a Mátrixban, ahogy Baudrillard írja, mindenki önmaga szimulákrumává lesz, ennek legkézzelfoghatóbb bizonyítéka a különbség a szereplöink megjelenésében a Mátrixon kívül és belül.

\section{Uralom és kódok}

„Hogy mi a Mátrix? Uralom” - mondja Morpheus, miután vázolja Neonak a Mátrix alapjait. Ez a tökéletes kontroll, az emberek testi és tudati szabályozása, annak a gondolatnak az elemelt és túlzó bemutatása, amelynek kezdetét Baudrillard az ürutazásban, kiteljesedését pedig magában a társadalomban véli felfedezni. Nincs különbség a Mátrix és a mi társadalmunk között, hisz mindkettő olyan „programozott mikrokozmosz, ahol semmi nem bizható a véletlenre"22. A Mátrix ráadásul nem mozdulatlan, abszolút reakcióképes, elég csak arra gondolnunk, amikor Neo száját eltüntetik az ügynökök, ${ }^{23}$ vagy amikor az épületet átalakítva egy pillanatra megtörik a hiperrealitás, és ezt a hibát Neo déjà vuként éli meg.

Baudrillard úgy gondolja, hogy azzal, hogy Kína eltörölte az ideogrammatikus írást és „csatlakozott” a latin ábécéhez, a békés együttélést választotta. Nemcsak egy világrendet, de annak hierarchiáját is elfogadta. Hasonlóképp egy közös programnyelvben íródik minden és mindenki a Mátrixban, ahol a szimuláció révén mindenfajta lingvisztikai, kulturális stb. különbség is csak látszólagos.

\footnotetext{
17 ibid. p. 177.

${ }^{18}$ Lásd a jelenet, amikor Neo figyelmét eltereli a piros ruhás nő.

${ }^{19}$ ibid. p. 180.

${ }^{20}$ Amennyiben persze elfogadjuk, hogy bár valóban több jelölt volt erre a szerepre, végül egyedül Neo találtatott annak lenni legalábbis az Ö életében.

${ }^{21}$ „You all look the same to me” mondja Morpheus az őt foglyul ejtő ügynöknek, miután az bemutatkozik neki.

22 ibid. p. 187.

${ }^{23}$ Akiknek a cinizmusa nem mellesleg kísértetiesen hasonlít arra a politikai cinizmusra, ami napjainkban sem ritka, sőt... http://www.kaleidoscopehistory.hu

Gerdesits Pál
} 
Kaleido scope
Journal of History of Culture, Science and Medicine

DOI: $10.17107 /$ KH.2020.20.169-174

\begin{abstract}
A háború
A háborúról azt írja Baudrillard, hogy „,nem kevésbé kegyetlen attól, hogy szimulákrum,”24 és nincs ez másképp a filmben sem, amiben egyrészt egy háborús szembenállás képezi a szituáció alapját, másrészt pedig hőseink, bár a Mátrix szimulált valóságában harcolnak, az ott elszenvedett sebeiket a való életben is megszerzik, sőt, meg is halhatnak így. Ettől függetlenül persze a háborúnak van egy igen pozitív hozadéka is: Zion népe egy emberként száll szembe a fenyegető veszéllyel, a lebeszélés ebben az értelemben a közös, legyőzhetetlennek tünő ellenség és a vele való elkerülhetetlen csata kettősségéből tevődik össze.
\end{abstract}

A háború szimulákrum-szerüsége kapcsán, illetve azt figyelembe véve, hogy a gép és ember harca folyamatos ciklikusságot követ, azaz, hogy amit most látunk, a Kiválasztott, Zion stb. már többször, programszerüen lefutott, joggal merülhet fel a gyanú, hogy hőseink tényleg a valóságban ébrednek-e fel, és nem pedig egy olyan látszatvalóságnak és látszatháborúnak vagyunk-e tanúi, mint amilyen Vietnám Baudrillard értelmezésében. ${ }^{25}$ William Merrin idézi Deleuze-t, aki Nietzsche Platón-kritikájával kapcsolatban írja, hogy minden barlang mögött kell lennie egy mélyebb, gazdagabb barlangnak, tehát nem kizárt, hogy Neoék csak a Mátrix egy újabb szintjére jutottak, de még mindig benne vannak. ${ }^{26}$

\title{
A filmmel kapcsolatos problémák
}

William Merrin ugyanebben a témában írott tanulmányában helyesen hívja fel a figyelmet arra az alapvető interferenciára, amit a film stiláris jegyei teremtenek Baudrillarddal szemben. Merrin a film által bemutatott bullett timeot Muybridge fényképészeti kísérleteivel hozza párhuzamba. ${ }^{27}$ és kétségkívül ez az attrakciófetisizált jelleg lehet az oka annak, hogy Trinity dominának öltözve, lassított felvételben ugrál háztetők között és ver halomra rendöröket (hogy a többi látványos és szürreális, néhol már-már paródiaszerü akciójelenetről ne is beszéljünk), így a film mondhatni áldoz a hiperrealitás oltárán.

Ez nyilvánvalóan, ahogy egyébként valószínűleg a baudrillardi gondolatok képi metaforává alakítása is, a film eladhatóságát hivatott lehetővé tenni, illetve mindezt feltöltötték a kor felszínességét méltán demonstráló filozófiai káosszal, gondolok itt például a különböző platóni, descartesi vagy buddhista eredetű gondolatok gátlástalan összeturmixolására. Merrin a film védelmében felveti, hogy ez a performatív maszlag ténylegesen arra szolgált, hogy nagy tömegeket szólíthasson meg, és mint az igazság trójai falova beguruljon a mozi világpiacára, de én személy szerint úgy gondolom, hogy sokkal inkább arról van szó, hogy találtak az alkotók egy nagyon jó filozófiai alapot, amit részben értettek csak meg ${ }^{28}$, így történhetett, hogy a film piaci termékként egy (kicsit?) azzá lett, ami ellen maga Baudrillard szólalt fel írásában.

A másik igen súlyos probléma, amire Merrin is felhívja a figyelmet, félig az előzőekből fakad. Az akciófilmes jelleg nyilván elkerülhetetlenül hordoz magában buta binaritáson alapuló agressziót. A film viszont egy olyan Mi-Ök distinkciót alkalmaz (többnyire Morpheus szájába adva ezen gondolatokat), amelyek azt indikálják, hogy mindenki ellenség (mivel potenciális ügynök), aki nem Mi vagyunk, és, bár elméletileg értük ${ }^{29}$ küzdünk, ne ódzkodjunk a gondolattól, hogy a tevékenykedésünk esetleg civil áldozatokkal járhat. Ez pedig megint inkább a szektások logikájához hasonló demagógiához tereli

\footnotetext{
24 ibid. p. 189.

${ }^{25}$ Baudrillard értelmezésébena vietnámi háború valójában végig egy Peking-Washington konfliktus volt.

${ }^{26}$ A halmozott hivatkozásért bocsánat. Forrás: Merrin, William: "Did You Ever Eat Tasty Wheat?":

Baudrillard and The Matrix. https://www.nottingham.ac.uk/scope/documents/2003/may-2003/merrin.pdf (utolsó letöltés dátuma: 2020. 01. 31.) (trans. Gerdesits Pál)

27 ibid. p. 9.

${ }^{28}$ Vagy részben akartak csak színre vinni.

${ }^{29} \mathrm{Az}$ emberiségért.
} 
Morpheusék csapatát. Érdekes egyébként megnézni, hogy milyen szélsőségek kezdték el alkalmazni a Mátrix fogalmiságát napjainkig bezárólag, ilyen (szélsőséges) példa a nyíltan faj-és nőgyülölő Red Pill mozgalom $^{30}$.

Szerettem volna bemutatni, hogy miképp képes egy szerző (páros) egyszerre követni és homlokegyenest szembe is menni egy olyan művel, ami egyértelműen meghatározó inspirációnak tekinthető saját alkotásuk tekintetében. Nem gondolom, hogy Lana és Lilly Wachowski holmi álságos felbujtók lennének, akik jó érzékkel kommercializáltak egy gondolkodót (ahogy azt sem gondolom, hogy Jean Baudrillard kifejezetten megsínylette volna az így nyert plusz figyelmet), abban viszont biztos vagyok, hogy a jelenség nem egyedi és magával a problémával kénytelen szembenézni mindenki, aki valamilyen szinten (akár befogadóként, akár alkotóként) érintett a kérdésben.

\section{Irodalom}

A Mátrix IMDb oldala https://www.imdb.com/title/tt0133093/ (utolsó letöltés dátuma: 2020. 01. 31.)

BAUDRILlARD, Jean: A szimulákrum elsőbbsége. In: Kiss, Kovács, Odorics (eds.): Testes könyv I. Szeged: Ictus és Jate, 1996.

Keanu Reeves' required reading for the Matrix. https://youtu.be/5zdUpQkDIr0 (utolsó letöltés dátuma: 2020. 03. 30.)

MERRIN, William: "Did You Ever Eat Tasty Wheat?": Baudrillard and The Matrix. https://www.nottingham.ac.uk/scope/documents/2003/may-2003/merrin.pdf (utolsó letöltés dátuma: 2020. 03. 30.) (trans. Gerdesits Pál)

REID, Rebecca: Welcome to the Red Pill: The angry men's rights group that 'knows what women want'. https://www.telegraph.co.uk/women/life/red-pill-mens-rights-anti-feminist-group-who-know-whatwomen-want/ (utolsó letöltés dátuma: 2020. 03. 30.)

\footnotetext{
30 Bővebben lásd: https://www.telegraph.co.uk/women/life/red-pill-mens-rights-anti-feminist-group-who-know-what-womenwant/ (utolsó letöltés dátuma: 2020. 03. 30.)
} 